\title{
THE RELATIVE AGE EFFECTS IN YOUNG SOCCER PLAYERS AND IT RELATIONS WITH THE COMPETITIVE LEVEL, SPECIFIC POSITION, MORPHOLOGICAL CHARACTERISTICS, PHYSICAL FITNESS AND TECHNICAL SKILLS.
}

\author{
Augusto Pedretti \\ Universidade Federal de Juiz de Fora, Juiz de Fora, Minas Gerais, Brasil \\ Alessandro Pedretti \\ Universidade do Porto, Porto, Portugal \\ João Brito de Oliveira Fernandes \\ Universidade do Porto, Porto, Portugal \\ António Natal Campos Rebelo \\ Universidade do Porto, Porto, Portugal \\ André Filipe Teixeira Seabra \\ Universidade do Porto, Porto, Portugal
}

\begin{abstract}
This study investigated the relative age effects (RAE) in young soccer players and it relations to morphological, technical and physical variables, in a sample of 267 male players from U17 and U19 categories. Our results showed significant differences by age quartiles in relation to the competition level (U17), field positions (U17 and U19) and the 30m sprint test (U19). In summary, no significant associations were identified on morphological characteristics, physical fitness and technical skills in relation to the RAE.
\end{abstract}

Key words: Competition level. Field position. Morphological characteristics. Physical fitness. Technical skills.

\section{Introduction}

The Fédération Internationale de Football Association (FIFA) imposes January 1 st as the starting date for every annual selection at international competitions (COBLEY et al., 2009; HELSEN, STARKES, \& VAN WINCKEL, 2000a; MUJIKA et al., 2009; MUSCH \& GRONDIN, 2001). Though the primary purpose of this selection criterion is the promotion of an equal likelihood of participation and success between players, as a large chronological age variability between players in the same age group is observed based on Musch and Grondin (2001) study. This variability is referred as relative age and it consequences as the relative age effect (COBLEY et al., 2009; MUSCH \& GRONDIN, 2001).

Several studies examined the RAE in young soccer players (DELORME, BOICHÉ, \& RASPAUD, 2010; DEPREZ et al., 2012; ROMANN \& FUCHSLOCHER, 2013), verifying an interindividual variability in their growth, biological maturation, physical fitness and technical skills (HELSEN et al., 2000b; MALINA et al., 2004b), and concluded that their lability may contribute to the existence of a RAE. Therefore, 
within a given chronological age group, young soccer players advanced in maturation tend to be, on average, taller, heavier and more powerful than their later matured counterparts (COELHO E SILVA et al., 2010; FIGUEIREDO et al., 2009a; SEABRA, MAIA, \& GARGANTA, 2001).

An over-representation of soccer players born in the first and second quartiles, and an under-representation of players born on the last quartiles is observed from Under-7 to Under-18 categories (DELORME, BOICHÉ, \& RASPAUD, 2010; DEPREZ et al., 2012). Despite a large decrease in RAE at regional and school representation can be seem, evidences pointing its presence in men's soccer are represented by the higher percentage of players that were born in the first quarter of the year at the selection for the professional levels, with peak values found for elite young athletes (PEDRETTI \& SEABRA, 2015). In relation to the player position, similar results can be observed, with defenders, midfielders and forwards being over-represented at the beginning of the selection year (ROMANN \& FUCHSLOCHER, 2013). However, the literature lacks a consensus on that matter, once the relationship between RAE and the player position was not found in some research (PEDRETTI \& SEABRA, 2015).

Some studies have also reported an eventual association between the RAE and anthropometric characteristics in young soccer players, with a significant difference in height across the birth quarters observed with higher values in the earlier-born soccer players (CARLING et al., 2009; GIL et al., 2013; HIROSE, 2009). According to Musch \& Grondin (2001), the RAE can be explained by two mechanisms: (1) older athletes tend to be taller, heavier, and stronger than younger athletes; and (2) older athletes are more likely to be identified as "talented" and be selected for all-star or representative teams. In fact, players who are born shortly after the cutoffs date are still up to an entire year of sports practice than late-born in their respective age group, allowing consequently to greater success in sports performance(HELSEN et al., 2000b; MALINA et al., 2004b).

Regarding the association between the RAE and physical fitness components (PEDRETTI \& SEABRA, 2015), some inconsistency can be found in the literature. For instance, Carling et al. (2009) and Gil et al. (2013) reported that soccer players who are born in the first and second quartiles of the year have a significantly higher performance than players who were born in the last quartiles, whereas Deprez et al. (2013) did not observe significant advantages in physical fitness components between the players born on the first quarter of the year and all other quarters. Well-developed physical capacities are believed to be an important aspect to reach success in soccer (REILLY, BANGSBO, \& FRANKS, 2000). For example, higher physical fitness represent an important component of young players testing batteries once it might delay both acute and accumulated fatigue, allowing a decreased relative exercise intensity during games (MENDEZ-VILLANUEVA et al., 2013).

In addition, studies on the influence of RAE on the technical performance of soccer players are scarce. According to Votteler \& Höner (2014), technical skills are less affected by RAE when compared to physical performance. Due the lack of studies on this topic in Under-17 and Under-19 Portuguese soccer players and to better understand this selection bias in Portugal, further studies should be carried out. Therefore, the aims of this study was (1) to examine the prevalence of the RAE in Under-17 and Under-19 Portuguese soccer players considering the competitive level (elite and non-elite) and field position (defenders, midfielders, forwards), and (2) to investigate possible differences on anthropometric characteristics, physical fitness components and technical skills in relation to the RAE, competitive levels and field position. 


\section{METHODS}

Participants

To implement our assessment, two hundred and sixty-seven portuguese men between 16-19 years, soccer players from 13 teams (5 elite, 8 non-elite) in categories Under-17 (U17) and Under-19 (U19) were selected and divided by us into an elite group $(n=130)$ competing in the first division of the national young league, and a nonelite group $(n=137)$ competing in a regional division. We also classified the players by playing position: defenders $(n=99)$, midfielders $(n=102)$, and forwards $(n=66)$. We conducted this study in accordance with accepted ethical standards and it was approved by the Scientific Committee of the Faculty of Sport of the University of Porto and the club officials. Players and their parents or legal guardians also consent the research.

Birth date distribution

To examine birth date distribution, the players were divided by us into four seasons of 3 months each considering the cut-off date fixed by FIFA from January 1 st to December 31. Therefore, the first quartile takes from January, February, until March (Q1), the second quartile includes April, May, June (Q2), the third quartile covers July, August, September (Q3), and the fourth quartile considers the months of October, November, and December (Q4).

\section{Protocol}

We evaluated all players in December 2013 at the Faculty of Sport of the University of Porto. The protocol included an interview, anthropometry, and a series of physical fitness and soccer-skill tests. Each player was tested on 2 occasions within a 1week period. Anthropometric dimensions and soccer-specific skills, speed and agility were measured during the initial visit. Jumping tests and intermittent endurance performances were assessed during the second visit. With the exception of anthropometry, all tests were administered outdoors on a soccer field with artificial grass. Prior to testing of physical capacities and soccer skills, the players performed a 12-min warm-up consisting of jogging and stretching exercises, as well as familiarization trials of each test. Players wore soccer clothing and shoes during all tests.

Height was measured with a fixed stadiometer (Holtain Ltd., UK) $( \pm 0.1 \mathrm{~cm})$; body mass with a body fat monitor (Tanita ${ }^{\circledR}, \mathrm{BC}-418 \mathrm{MA}$, USA) $( \pm 0.1 \mathrm{~kg})$. Each measurement was taken twice and the mean was retained for analysis. Players wore light clothing and shoes were removed. Speed was evaluated with a $30-\mathrm{m}$ sprint test. Elapsed times were measured using 3 pairs of photoelectric cells (Speed Trap II, Brower Timing Systems, USA), positioned at the starting line and at 5 and $30 \mathrm{~m}$. Players were instructed to run as fast as possible from a standing position $30 \mathrm{~cm}$ behind the starting line. The better (fastest) of 2 trials was retained for analysis. Agility was evaluated by the T-test (SEMENICK, 1990). The subject began with both feet $30 \mathrm{~cm}$ behind the starting point (A). The player sprinted forward $10 \mathrm{~m}$ to point $\mathrm{B}$ and touched a marker (cone) with the right hand, then sprinted $5 \mathrm{~m}$ to the left and touched another marker (C) with the left hand, then sprinted $10 \mathrm{~m}$ to the right and touched a third marker (D) with the right hand, and finally sprinted back to point $B$ and touched the marker with the left hand, after which he turned $90^{\circ}$ and returned to the starting point A running through the 
finish line. One pair of photoelectric cells was placed at the starting/finishing point (A) to record the elapsed time. Players were instructed to run as fast as possible. The better (fastest) of 2 trials was retained for analysis. Jumping height was evaluated with a squat jump (SJ) and a countermovement jump (CMJ) on a special mat (Digitime 1000, Digitest, Finland), following the protocol of Bosco, Luhtanen, \& Komi (1983). The SJ was performed with a squat starting position: knees flexed at $90^{\circ}$ and hands on hips. From this position, the player made a maximal vertical jump and then landed with straight knees on the mat. For the CMJ, the player was standing erect; after flexing the knees to the squat position, he jumped vertically as high as possible maintaining hands on hips. Two trials were given for each jump and the better of the two trials was retained for analysis. The Yo-Yo intermittent endurance test - level 2 (Yo-Yo IE2) required repeated $2 \times 20-\mathrm{m}$ runs (shuttles) between the start and finish line at progressively increased speeds controlled by audio bleeps from a tape-recorder; there was a 5-s period of rest between runs (Bangsbo, 1996). The aim of the test was to perform as many shuttles as possible. When the player failed twice to reach the finish line in time, the distance covered was recorded and used as the test result. Only one trial was given. Two soccer-specific technical skill tests were adapted from the Ghent Youth Soccer Project (VAEYENS et al., 2006): ball control and dribbling. In the ball control test, the player had to keep the ball in the air without using the arms or hands. The score recorded was the number of hits of the ball before it fell to the floor. Two trials were administered, although the player could start the trial again if he failed to contact the ball twice in the initial attempt. In the dribbling test, the player was instructed to dribble the ball around nine cones (2-m apart) in a slalom fashion from the start to end lines and return. The purpose was to complete the drill in the fastest time possible without knocking down the cones. If a cone was knocked over, the player had to place it upright and continue the test. Performance was measured using one pair of photoelectric cells, positioned at the start/finish line. Players were instructed to slalom as fast as possible from a standing position $30 \mathrm{~cm}$ behind the starting line. The average of the two trials for each test was used in the analysis. The official ball of the Portuguese Championships (Adidas Europass; 5-size ball) was used in the skill tests, with a pressure of 0.8 bar. Technical errors of measurement for anthropometry were $0.24 \mathrm{~cm}$ for height, and 0.17 $\mathrm{kg}$ for weight. Interclass correlation coefficients were 0.97 for 5 - and 30-m sprints; 0.95 for agility; 0.97 and 0.89 for SJ and CMJ, respectively; 0.70 and 0.89 for the peak torque of the knee extensor and flexor muscles, respectively; and 0.70 and 0.99 for ball control and dribbling tests, respectively. A replicate test was not given for the Yo-Yo IE2.

Statistical analysis

Results showed either as means (standard deviations) or proportions. Pearson's chi-square tests were used to identify differences in proportions between quartiles. We conducted a three-way analysis of variance (ANOVA) to examine the effects of quartiles $\left(1^{\text {st }}, 2^{\text {nd }} 3^{\text {rd }}, 4^{\text {th }}\right)$, competition level (elite, non-elite) and field position (defender, midfielder, forward) on the anthropometric characteristics, physical fitness components and technical skills. We conducted the analysis by using The Bonferroni test for multiple comparisons to check for specific differences by quartile, competition level and field position. We set a significance level at .05. Statistical analyses were performed using SPSS 21.0. 


\section{Results}

Table 1 shows the birth date distribution for young soccer players in each category according to competition level and field position. Significant higher percentages of U17 soccer players born in the first two quarters compared with players born in the last quarters. Significant higher percentages of U17 soccer players in both competition levels, and midfielders and forwards born in the first two quarters compared with the last quarters. We were not able to observe any significant differences in defenders on the birth date distribution. For the U19 category, though we were able report higher percentages in players (elite and non-elite) born in the first two quarters compared with the last quarters, we could not identify any significant differences for competitive level. More than 55\% of midfielders and forwards U19 soccer players born in the first two quartiles. No significant differences were identified by us in defenders of U19 soccer players.

Table 1. Birth date distribution for young soccer players in each category according competitive level and position.

\begin{tabular}{|c|c|c|c|c|c|c|}
\hline & & Quartiles & & & & \\
\hline Categories & Characteristics & Q1 & Q2 & Q3 & Q4 & $X^{2}(P)$ \\
\hline Under 17 & Total & 44 & 40 & 20 & 14 & $22.06 * *$ \\
\hline & Competitive level & & & & & \\
\hline & Non-elite & 23 & 23 & 11 & 11 & $8.47 *$ \\
\hline & Elite & $21(42 \%)$ & $17(34 \%)$ & $9(18 \%)$ & $3(6 \%)$ & $15.60 * *$ \\
\hline & Field position & & & & & \\
\hline & Defender & 19 & 12 & 11 & $7(14.3 \%)$ & 6.2 \\
\hline & Midfielder & 13 & 20 & $6(14 \%)$ & $4(9.3 \%)$ & $14.77 *$ \\
\hline & Forward & 12 & $8(30.8 \%)$ & $3(11.5 \%)$ & $3(11.5 \%)$ & $8.77 *$ \\
\hline Under 19 & Total & $\overrightarrow{39}$ & 48 & 35 & 27 & 6.14 \\
\hline & Competitive level & & & & & \\
\hline & Non-elite & 16 & $20(29 \%)$ & $20(29 \%)$ & 13 & 2.01 \\
\hline & Elite & 23 & $28(35 \%)$ & 15 & $1 \overline{4}$ & 6.70 \\
\hline & Field position & & & & & \\
\hline & Defender & $13(26 \%)$ & $14(28 \%)$ & $11(22 \%)$ & $12(24 \%)$ & 0.40 \\
\hline & Midfielder & 21 & 12 & 19 & $7(11.9 \%)$ & $8.46^{*}$ \\
\hline & Forward & $5(12.5 \%)$ & $22(55 \%)$ & $5(12.5 \%)$ & $8(20 \%)$ & $18.80^{* *}$ \\
\hline
\end{tabular}

(Q: Quartile; $\mathrm{X}^{2}$ : Chi-square test; P-value: $\left.{ }^{*} \mathrm{p}<0.05,{ }^{*} \mathrm{p} \leq 0.001\right)$

Table 2 and 3 show the results of the three-way ANOVA models for anthropometric characteristics, physical fitness components and technical skills for both categories according to quartiles, competition levels and field positions. Analyses for U17 category revealed only a significant main effect for competition levels. Elite soccer players tended to be taller and heavier and to perform better than their non-elite counterparts in all physical fitness components and technical skills. Except in the physical fitness composite and juggling and dribbling soccer skills tests, there was no significant differences being observed by us between field positions. In these variables 
midfielders and forwards presented significantly higher values than defenders. We did not find any significant main effects between quartiles for U17. For the U19 category we were only able to observe a significant main effect for quartiles in the $30 \mathrm{~m}$ sprint test. Soccer players who were born in the first two quarters were significantly faster in $30 \mathrm{~m}$ sprint compared with players born in the last quarters. Elite players tended to be taller and heavier and performed better than their non-elite counterparts in all physical fitness (except CMJ and 30m sprint) and technical skills tests. Midfielders performed significantly better in the juggling test than defenders and forwards. 
Table 2. Mean values (standard deviations). Three-way analysis of variance (ANOVA) of different anthropometric characteristics, physical

fitness and technical skills for Under 17 soccer players according to quartiles, competitive level and field position.

\begin{tabular}{|c|c|c|c|c|c|c|c|c|c|c|}
\hline & Height (m) & Weight (kg) & CMJ $(\mathrm{cm})$ & SP5 (s) & SP30 (s) & Agility (s) & YYIE2 (m) & Juggling & Dribbling (s) & Composite \\
\hline \multicolumn{11}{|l|}{ Quartiles } \\
\hline 1 & $1.73 \pm 0.01$ & $66.46 \pm 1.27$ & $39 \pm 0.01$ & $1.09 \pm 0.01$ & $4.36 \pm 0.03$ & $9.17 \pm 0.06$ & $1079.80 \pm 59.34$ & $119.00 \pm 7.33$ & $16.10 \pm 0.26$ & $1.08 \pm 0.44$ \\
\hline 2 & $1.74 \pm 0.01$ & $67.10 \pm 1.50$ & $36 \pm 0.01$ & $1.08 \pm 0.02$ & $4.35 \pm 0.03$ & $9.24 \pm 0.07$ & $1050.96 \pm 63.57$ & $112.06 \pm 8.48$ & $16.03 \pm 0.31$ & $0.039 \pm 0.52$ \\
\hline 3 & $1.71 \pm 0.02$ & $65.29 \pm 2.22$ & $37 \pm 0.01$ & $1.08 \pm 0.02$ & $4.32 \pm 0.05$ & $9.12 \pm 1.00$ & $977.33 \pm 89.49$ & $88.04 \pm 12.58$ & $15.82 \pm 0.47$ & $0.048 \pm 0.78$ \\
\hline 4 & $1.72 \pm 0.02$ & $67.01 \pm 2.60$ & $38 \pm 0.02$ & $1.08 \pm 0.03$ & $4.41 \pm 0.05$ & $9.25 \pm 0.12$ & $894.67 \pm 122.87$ & $126.23 \pm 14.76$ & $16.24 \pm 0.54$ & $0.017 \pm 0.91$ \\
\hline \multicolumn{11}{|l|}{ CL } \\
\hline Elite & $1.73 \pm 0.01$ & $65.10 \pm 1.46$ & $38 \pm 0.01$ & $1.03 \pm 0.02$ & $4.25 \pm 0.03$ & $9.01 \pm 0.06$ & $1194.06 \pm 55.52$ & $134.47 \pm 8.26$ & $15.31 \pm 0.30$ & $3.35 \pm 0.51$ \\
\hline Non-elite & $1.72 \pm 0.01$ & $67.91 \pm 1.26$ & $37 \pm 0.01$ & $1.13 \pm 0.01$ & $4.46 \pm 0.03$ & $9.36 \pm 0.06$ & $819.08 \pm 62.77$ & $88.88 \pm 7.18$ & $16.71 \pm 0.26$ & $-2.03 \pm 0.44$ \\
\hline \multicolumn{11}{|l|}{$\mathbf{F P}$} \\
\hline Defender & $1.74 \pm 0.01$ & $68.44 \pm 1.52$ & $37 \pm 0.01$ & $1.09 \pm 0.02$ & $4.39 \pm 0.03$ & $9.16 \pm 0.07$ & $928.43 \pm 64.50$ & $94.85 \pm 8.63$ & $16.97 \pm 0.32$ & $-0.64 \pm 0.53$ \\
\hline Midfielder & $1.72 \pm 0.01$ & $65.14 \pm 1.55$ & $39 \pm 0.01$ & $1.08 \pm 0.02$ & $4.36 \pm 0.03$ & $9.27 \pm 0.07$ & $1001.97 \pm 70.47$ & $127.92 \pm 8.79$ & $15.37 \pm 0.33$ & $1.14 \pm 0.54$ \\
\hline Forward & $1.72 \pm 0.01$ & $65.65 \pm 1.93$ & $38 \pm 0.01$ & $1.08 \pm 0.02$ & $4.31 \pm 0.04$ & $9.15 \pm 0.09$ & $1116.89 \pm 85.93$ & $109.08 \pm 11.02$ & $15.73 \pm 0.40$ & $1.22 \pm 0.67$ \\
\hline \multicolumn{11}{|c|}{ Results of analysis of variance for each variable } \\
\hline SOV & $\mathrm{F}$ & $\mathrm{F}$ & $\mathrm{F}$ & $\mathrm{F}$ & $\mathrm{F}$ & $\mathrm{F}$ & $\mathrm{F}$ & $\mathrm{F}$ & $\mathrm{F}$ & $\mathrm{F}$ \\
\hline Quartiles & 0.48 & 0.23 & 0.89 & 0.11 & 0.21 & 0.37 & 0.45 & 1.90 & 0.12 & 0.39 \\
\hline CL & 0.33 & 2.48 & 1.18 & $17.39 * *$ & $22.92 * *$ & $13.59 * *$ & $10.92 *$ & $15.48 * *$ & $8.91 *$ & $53.69 * *$ \\
\hline FP & 0.47 & 1.18 & 0.34 & 0.24 & 1.86 & 0.98 & 1.27 & $3.63^{*}$ & $6.92 *$ & $4.53^{*}$ \\
\hline $\mathrm{Q}^{*} \mathrm{CL}$ & 1.12 & 0.55 & 0.78 & 0.82 & 0.88 & 0.19 & 0.36 & 2.15 & 0.36 & 1.05 \\
\hline $\mathrm{Q} * \mathrm{FP}$ & 0.49 & 0.60 & 1.16 & 0.83 & 1.19 & 0.69 & 1.95 & 0.47 & 0.89 & 0.88 \\
\hline CL*FP & 0.26 & 0.55 & 0.31 & 0.26 & 0.24 & 0.43 & 0.29 & 0.54 & 2.13 & 0.06 \\
\hline $\mathrm{Q} * \mathrm{CL} * \mathrm{FP}$ & 0.88 & 1.11 & 1.08 & 0.31 & 0.64 & 1.34 & 0.34 & 1.11 & 0.70 & 1.65 \\
\hline
\end{tabular}

(m: meter; kg: kilogram; cm: centimeter; s: seconds; CMJ: Counter movement jump; SP5: Speed 5-m; SP30: Speed 30-m; YYIE2: Yo-Yo intermittent endurance test - level 2; CL: Competitive level; FP: Field position; SOV: Sources of variation; F: F-test; Q: Quartiles; P-value: ${ }^{*} \mathrm{p}<0.05,{ }^{*} \mathrm{p} \leq 0.001$ ) 
Table 3. Mean values (standard deviations). Three-way analysis of variance (ANOVA) of different anthropometric characteristics, physical fitness and technical skills for Under 19 soccer players according to quartiles, competitive level and field position.

\begin{tabular}{|c|c|c|c|c|c|c|c|c|c|c|}
\hline & Height (m) & Weight (kg) & CMJ (cm) & SP5 (s) & SP30 (s) & Agility (s) & YYIE2 (m) & Juggling & Dribbling (s) & Composite \\
\hline \multicolumn{11}{|l|}{ Quartiles } \\
\hline 1 & $1.77 \pm 0.01$ & $73.20 \pm 1.45$ & $39 \pm 0.01$ & $1.06 \pm 0.08$ & $4.26 \pm 0.03$ & $9.11 \pm 0.06$ & $1169.03 \pm 81.93$ & $140.57 \pm 10.27$ & $15.51 \pm 0.27$ & $0.15 \pm 0.74$ \\
\hline 2 & $1.73 \pm 0.01$ & $69.57 \pm 1.21$ & $39 \pm 0.01$ & $1.07 \pm 0.08$ & $4.31 \pm 0.02$ & $8.99 \pm 0.05$ & $1220.04 \pm 64.64$ & $123.86 \pm 8.16$ & $15.68 \pm 0.22$ & - \\
\hline 3 & $1.75 \pm 0.02$ & $68.95 \pm 1.69$ & $39 \pm 0.01$ & $1.08 \pm 0.09$ & $4.28 \pm 0.04$ & $8.94 \pm 0.07$ & $1290.93 \pm 91.25$ & $114.33 \pm 11.98$ & $15.34 \pm 0.32$ & $0.5 \overline{6} \pm 0.86$ \\
\hline 4 & $1.75 \pm 0.01$ & $70.86 \pm 1.55$ & $37 \pm 0.01$ & $1.09 \pm 0.09$ & $4.41 \pm 0.03$ & $9.10 \pm 0.07$ & $1233.78 \pm 84.40$ & $119.57 \pm 11.00$ & $15.68 \pm 0.29$ & - \\
\hline \multicolumn{11}{|l|}{$\mathbf{C L}$} \\
\hline Elite & $1.76 \pm 0.01$ & $72.43 \pm 1.06$ & $39 \pm 0.01$ & $1.06 \pm 0.06$ & $4.28 \pm 0.14$ & $8.86 \pm 0.04$ & $1409.07 \pm 55.60$ & $142.72 \pm 7.49$ & $15.18 \pm 0.20$ & $1.55 \pm 0.54$ \\
\hline Non-elite & $1.73 \pm 0.01$ & $68.86 \pm 1.04$ & $38 \pm 0.01$ & $1.10 \pm 0.10$ & $4.33 \pm 0.18$ & $9.20 \pm 0.04$ & $1047.81 \pm 59.10$ & $106.44 \pm 7.28$ & $15.93 \pm 0.19$ & $-2.20 \pm 0.52$ \\
\hline \multicolumn{11}{|l|}{$\mathbf{F P}$} \\
\hline Defender & $1.76 \pm 0.01$ & $72.57 \pm 1.07$ & $39 \pm 0.01$ & $1.07 \pm 0.09$ & $4.29 \pm 0.17$ & $8.97 \pm 0.05$ & $1226.51 \pm 61.94$ & $105.64 \pm 7.59$ & $15.87 \pm 0.20$ & $-0.42 \pm 0.54$ \\
\hline Midfielder & $1.73 \pm 0.01$ & $69.27 \pm 1.18$ & $37 \pm 0.01$ & $1.09 \pm 0.09$ & $4.34 \pm 0.15$ & $9.05 \pm 0.05$ & $1276.29 \pm 63.66$ & $147.14+8.10$ & $15.51 \pm 0.22$ & $-0.37 \pm 0.58$ \\
\hline \multirow[t]{2}{*}{ Forward } & $1.74 \pm 0.01$ & $70.10 \pm 1.56$ & $40 \pm 0.01$ & $1.06 \pm 0.07$ & $4.27 \pm 0.15$ & $9.08 \pm 0.07$ & $1182.53 \pm 83.22$ & $120.96 \pm 11.06$ & $15.28 \pm 0.29$ & $-0.19 \pm 0.79$ \\
\hline & \multicolumn{10}{|c|}{ Results of analysis of variance for each variable } \\
\hline SOV & $\mathrm{F}$ & $\mathrm{F}$ & $\mathrm{F}$ & $\mathrm{F}$ & $\mathrm{F}$ & $\mathrm{F}$ & $\mathrm{F}$ & $\mathrm{F}$ & $\mathrm{F}$ & $\mathrm{F}$ \\
\hline Quartiles & 1.16 & 1.64 & 1.40 & 0.53 & $2.85 *$ & 1.58 & 0.33 & 1.12 & 0.32 & 1.76 \\
\hline $\mathrm{CL}$ & 5.43 & 5.76 & 0.45 & 6.81 & 1.22 & $28.64 * *$ & $19.82 * *$ & $12.05 * *$ & $7.31^{*}$ & $25.09 * *$ \\
\hline FP & 2.63 & 2.30 & 1.27 & 1.23 & 2.97 & 1.12 & 0.42 & $7.04 * *$ & 1.57 & 0.03 \\
\hline $\mathrm{Q} * \mathrm{CL}$ & 2.00 & 1.86 & 0.22 & 0.57 & 0.89 & 1.04 & 0.24 & 0.20 & 0.17 & 0.45 \\
\hline $\mathrm{Q}^{*} \mathrm{FP}$ & 0.53 & 0.52 & 0.72 & 1.46 & 1.55 & 1.61 & 0.49 & 1.20 & 0.58 & 1.66 \\
\hline CL*FP & 0.21 & 0.31 & 0.33 & 0.83 & 0.74 & 1.59 & 0.12 & 2.04 & 0.60 & 0.38 \\
\hline $\mathrm{Q}^{*} \mathrm{CL}^{*} \mathrm{FP}$ & 0.51 & 0.91 & 1.24 & 1.16 & 0.82 & 2.16 & 1.93 & 0.97 & 1.65 & $2.32 *$ \\
\hline
\end{tabular}

(m: meter; kg: kilogram; cm: centimeter; s: seconds; CMJ: Counter movement jump; SP5: Speed 5-m; SP30: Speed 30-m; YYIE2: Yo-Yo intermittent endurance test - level 2; CL: Competitive level; FP: Field position; SOV: Sources of variation; F: F-test; Q: Quartiles; P-value: ${ }^{*} p<0.05, * * p \leq 0.001$ ) 


\section{Discussion}

As the main question of this study, we found that a significant higher percentage of players in the elite and non-elite teams (Under-17), midfielders and forwards (Under-17 and Under-19) were born in the first age quartile in relation to the last quartile. This significant association between age quartiles was also found for the $30-\mathrm{m}$ sprint in Under-19. In summary, even though a higher proportion of young soccer players born in the first quartile have been observed, we were not able to observe a significant RAE on morphological characteristics, physical fitness and technical skills. Analyses for Under-17 category revealed a significant main effect only for the competition levels. In relation to the field positions no significant differences were observed, with exception physical fitness composite and juggling and dribbling soccer skills tests.

Recent studies argue that there is a consensus about the presence of a RAE in men's soccer (PEDRETTI \& SEABRA, 2015), and Cobley et al. (2009) in their meta-analysis of RAE in sport, showed a small-moderate effect for individuals aged 15-18 years that decline for older individuals. Similar results were also observed in this study, with significant higher percentages of soccer players being found to be born in the first two age quartiles at the U17 but not for the U19. Some reasons might account for these findings. First, young athletes differ in timing and tempo of development, growth and maturation (MALINA, BOUCHARD, \& BAR-OR, 2004a) increasing the RAE. Second, each player will with time, reach the adult stage and achieve maturity (COBLEY et al., 2009), levelling off the differences existing in the younger age groups (MALINA, BOUCHARD, \& BAR-OR, 2004a).

The finding of a RAE by competitive level in the U17 agrees with Mujika et al. (2009), showing that the percentage of players born in the first quarter of the selection year is high for professionals, with peak values being found for the youth elite and evidences of a large decrease along the regional and school representation. Augste and Lames (2011) found significant relationships between the RAE and success indicators taken from final rankings (rank, points scored, and goals against) for the teams in each of the three leagues analyzed. Although relatively younger athletes are significantly under-represented in early stages of the selection process, and given that we could not identify any significant differences of a RAE by competitive level in the U19, many of them still manage to navigate through the sport development system and find their way into more senior levels of competition.

As previously referred, we found significant higher percentages of midfielders and forwards born in the first two quarters compared with the last quarters for both U17 and U19, but the relationship between RAE and the specific position is controversial. Jimenez \& Pain (2008) reported no clear differences in the distribution of birth dates for specific position, but Romann \& Fuchslocher ( 2013) found that defenders, midfielders and forwarders born in the first two quarters of the year were overrepresented at the beginning of the selection period. While these results provide evidence that player position are not affect by the strength of RAE, those observations were not evident for our U17 and U19 Portuguese soccer players sample, highlighting the need for additional research to better understand the factors underpinning these relationships.

Carling et al. (2009) and Gil et al. (2013) found significant differences between the RAE, anthropometry and physical fitness, contrasting with our results where the only significant association found was for the 30-m sprint in the U19 sample and with findings from other research (DEPREZ et al., 2013) that observed no differences in morphological variables and anaerobic performance between age quartiles. Several studies (BAXTERJONES \& HELMS, 1994a; BAXTER-JONES et al. 1994b; BREWER et al. 1992; VERHULST, 1992) attributed the RAE solely to the physical advantages of the relatively older players. However, despite higher percentages of U17 born in the first two quarters were 
found in this study, our results were not biased in that way. Explanations based on physical maturity seemed to be particularly convincing given that age differences up to 1- or 2-years can indeed have a significant impact in the stature and weight of children in youth sport programs (BAXTER-JONES et al., 1994b; MALINA, 1994).

In this study, position-specific differences in terms of size, functional and skill tests were identified between elite and non-elite, identifying additionally that the defenders showed to be taller and heavier, when investigating differences between players position. Our findings corroborate other studies conducted with adult and adolescent players (12-19 years), reporting respectively, differences in body size between elite and amateur players (LE GALL et al., 2010) and that defenders were taller and heavier while midfielders were leaner and shorter (CARLING, LE GALL, \& MALINA, 2012; COELHO E SILVA et al., 2010; LAGOPEÑAS et al., 2011).

These characteristics are generally expected given the demands associated with the respective positions, as high physical contact and jumping to contest aerial balls and intercept long ball passes and crosses are expected among defenders. By their turn, midfielders and forwards are required to move more skillfully and efficiently over greater distances throughout the pitch, so a smaller size and especially a lower body mass may be an advantage (BUCHHEIT et al., 2010).

Moreover, successful performance in skill-related activities like ball control are important determinants of success in soccer, once technical skills appeared to discriminate elite from non-elite defenders, beyond stature, body mass, vertical jump scores (HANSEN et al., 1999; REILLY, BANGSBO, \& FRANKS, 2000; VAEYENS et al., 2006). Research have been shown that performance on intermittent high-intensity tests is related to the distance covered during a match (BANGSBO, MOHR, \& KRUSTRUP, 2006; KRUSTRUP et al., 2003; MOHR, KRUSTRUP, \& BANGSBO, 2003) and comparisons between elite and nonelite players also suggest a need for greater ability to sustain high intensity tasks (BANGSBO, 1994; REILLY, BANGSBO, \& FRANKS, 2000), making moderate to high levels of speed, agility, and aerobic endurance very important features for elite soccer players.

In summary, no significant RAE was observed on morphological characteristics, physical fitness components (except for 30-m sprint in U19) and technical skills, despite the higher proportion of young soccer players born in the first and second quartiles (significant only for the U17). We still found that elite soccer players were taller and heavier and perform better than their non-elite counterparts in all physical fitness components and technical skills, and defenders were taller and heavier than midfielders and forwards, displaying yet lower physical fitness and technical skills.

Although this study presents novel findings some limitations should be considered. First, a relative small number of participants were sampled and consequently the generalizability of the results may be limited. Second, this study only examined the RAE during a point of time (December 2013), which is not necessarily a reflection of the general situation over a longer time period. These limitations are not unique to this type of study but should be considered when interpreting the results and for further research in this area.

\section{O EFEITO DA IDADE RELATIVA EM JOVENS FUTEBOLISTAS E SUAS RELAÇÕES COM O NÍVEL DE COMPETIÇÃO, POSIÇÃO ESPECÍFICA, CARACTERÍSTICAS MORFOLÓGICAS, CAPACIDADE FÍSICA E HABILIDADES TÉCNICAS}

\section{Resumo}

Este estudo investigou o efeito da idade relativa (EIR) em jovens futebolistas e suas relações com variáveis morfológicas, técnicas e físicas em uma amostra de 267 jogadores de categorias 
Sub17 e Sub19. Nossos resultados mostraram diferenças significativas em função dos quartis etários em relação ao nível de competição (Sub17), posição de campo (Sub17 e Sub19) e teste de velocidade de 30m (Sub19). Em geral, nenhuma associação significativa foi identificada nas características morfológicas, capacidades físicas e habilidades técnicas em relação ao EIR. Palavras-chave: Nível de competição. Posição de campo. Características morfológicas. Capacidade física. Habilidades técnicas.

\section{EL EFECTO DE LA EDAD RELATIVA DE LOS FUTBOLISTAS JÓVENES Y SU RELACIÓN CON EL NIVEL DE COMPETENCIA, PUESTO ESPECÍFICO, LA MORFOLOGÍA, LA CAPACIDAD FÍSICA Y HABILIDADES TÉCNICAS}

\section{Resumen}

Este estudio investigó el efecto de la edad relativa (EIR) en futbolistas jóvenes y su relación con variables morfológicas, técnicas y físicas en una muestra de 267 jugadores de las categorías Sub17 y Sub19. Nuestros resultados mostraron diferencias significativas según cuartiles de edad en comparación con el nivel de competencia (Sub17), la posición de campo (Sub17 y Sub19) y la prueba de velocidad de 30 metros (U19). En general, no hay asociación significativa fue identificado en las habilidades morfológicas, físicas y habilidades técnicas en relación con el EIR.

Palabras clave: Nivel de competencia. Posición en el campo. Morfología. Capacidad física. Habilidades técnicas.

\section{References}

AUGSTE, C.; LAMES, M. The relative age effect and success in German elite U-17 soccer teams. Journal of sports sciences, v. 29, n. 9, p. 983-7, Jun 2011. Disponível em: < http://www.ncbi.nlm.nih.gov/pubmed/21604225 >.

BANGSBO, J. Fitness training in football: a scientific approach. August Krogh Inst., University of Copenhagen, 1994.

BANGSBO, J. Yo-Yo tests. Copenhagen: HO + Storm, 1996.

BANGSBO, J.; MOHR, M.; KRUSTRUP, P. Physical and metabolic demands of training and match-play in the elite football player. Journal of sports sciences, v. 24, n. 07, p. 665-674.

BAXTER-JONES, A.; HELMS, P. Born too late to win? Nature, v. 370, n. 6486, p. 186, 1994a.

BAXTER-JONES, A. et al. Growth and development of male athletes: implications for identification of talent. Journal of Sports Sciences, v. 12, p. 156, 1994 b.

BOSCO, C.; LUHTANEN, P.; KOMI, P. V. A simple method for measurement of mechanical power in jumping. Eur J Appl Physiol, v. 50, n. 2, p. 273-282, 1983.

BREWER, J. et al. The influence of birth date and physical development on the selection of a male junior international soccer squad. Journal of Sports Sciences, v. 10, p. 561-562, 1992. 
BUCHHEIT, M. et al. Match running performance and fitness in youth soccer. Int J Sports Med, v. 31, n. 11, p. 818-25, Nov 2010.

CARLING, C.; LE GALL, F.; MALINA, R. M. Body size, skeletal maturity, and functional characteristics of elite academy soccer players on entry between 1992 and 2003. Journal of sports sciences, v. $30, \quad$ n. 15, p. 1683-93, 2012. Disponível em: < http://www.ncbi.nlm.nih.gov/pubmed/22292471 >.

CARLING, C. et al. Do anthropometric and fitness characteristics vary according to birth date distribution in elite youth academy soccer players? Scand J Med Sci Sports, v. 19, n. 1, p. 3-9, Feb 2009. Disponível em: < http://www.ncbi.nlm.nih.gov/pubmed/19000100 >.

COBLEY, S. et al. Annual age-grouping and athlete development. Sports Medicine, v. 39, n. 3, p. 235-256, 2009.

COELHO E SILVA, M. J. et al. Discrimination of u-14 soccer players by level and position. Int J Sports Med, v. 31, n. 11, p. 790-6, Nov 2010. Disponível em: < http://www.ncbi.nlm.nih.gov/pubmed/20830654 >.

DELORME, N.; BOICHÉ, J.; RASPAUD, M. Relative age effect in elite sports: Methodological bias or real discrimination? European Journal of Sport Science, v. 10, n. 2, p. 91-96, 2010.

DEPREZ, D. et al. Relative age, biological maturation and anaerobic characteristics in elite youth soccer players. Int J Sports Med, v. 34, n. 10, p. 897-903, Oct 2013. Disponível em: < http://www.ncbi.nlm.nih.gov/pubmed/23700327 >.

DEPREZ, D. et al. Relative age effect and Yo-Yo IR1 in youth soccer. Int J Sports Med, v. 33, n. 12, p. 987-93, Dec 2012. Disponível em: < http://www.ncbi.nlm.nih.gov/pubmed/22791620>.

FIGUEIREDO, A. J. et al. Youth soccer players, 11-14 years: maturity, size, function, skill and goal orientation. Annals of Human Biology, v. 36, n. 1, p. 60-73, 2009a. ISSN 03014460 .

GIL, S. M. et al. Relationship between the relative age effect and anthropometry, maturity and performance in young soccer players. J Sports Sci, Sep 20 2013. Disponível em: < http://www.ncbi.nlm.nih.gov/pubmed/24050650 >.

HANSEN, L. et al. Development of muscle strength in relation to training level and testosterone in young male soccer players. Journal of Applied Physiology, v. 87, n. 3, p. 1141-1147, 1999.

HELSEN, W. F. et al. The roles of talent, physical precocity and practice in the development of soccer expertise. J Sports Sci, v. 18, n. 9, p. 727-36, Sep 2000b. Disponível em: < http://www.ncbi.nlm.nih.gov/pubmed/11043898 >.

HELSEN, W. F.; STARKES, J. L.; VAN WINCKEL, J. Effect of a change in selection year on success in male soccer players. American Journal of Human Biology, v. 12, n. 6, p. 729735, 2000a. 
HIROSE, N. Relationships among birth-month distribution, skeletal age and anthropometric characteristics in adolescent elite soccer players. J Sports Sci, v. 27, n. 11, p. 1159-66, Sep 2009. Disponível em: < http://www.ncbi.nlm.nih.gov/pubmed/19724967 >.

JIMENEZ, I. P.; PAIN, M. T. Relative age effect in Spanish association football: its extent and implications for wasted potential. J Sports Sci, v. 26, n. 10, p. 995-1003, Aug 2008. Disponível em: < http://www.ncbi.nlm.nih.gov/pubmed/18608842 >.

KRUSTRUP, P. et al. The yo-yo intermittent recovery test: physiological response, reliability, and validity. Medicine and science in sports and exercise, v. 35, n. 4, p. 697-705, 2003.

LAGO-PEÑAS, C. et al. Anthropometric and physiological characteristics of young soccer players according to their playing positions: relevance for competition success. The Journal of Strength \& Conditioning Research, v. 25, n. 12, p. 3358-3367, 2011.

LE GALL, F. et al. Anthropometric and fitness characteristics of international, professional and amateur male graduate soccer players from an elite youth academy. J Sci Med Sport, v. 13, n. 1, p. 90-95, 2010.

MALINA, R. M. Physical growth and biological maturation of young athletes. Exercise and sport sciences reviews, v. 22, n. 1, p. 280-284, 1994.

MALINA, R. M.; BOUCHARD, C.; BAR-OR, O. Growth, maturation, and physical activity. Champaign, IL: Human Kinetics 2004a.

MALINA, R. M. et al. Maturity-associated variation in the growth and functional capacities of youth football (soccer) players 13-15 years. Eur J Appl Physiol, v. 91, n. 5-6, p. 555-62, May 2004b. Disponível em: < http://www.ncbi.nlm.nih.gov/pubmed/14648128 >.

MENDEZ-VILLANUEVA, A. et al. Match play intensity distribution in youth soccer. Int J Sports Med, v. 34, n. 2, p. 101-110, 2013.

MOHR, M.; KRUSTRUP, P.; BANGSBO, J. Match performance of high-standard soccer players with special reference to development of fatigue. Journal of sports sciences, v. 21, n. 7, p. 519-528, 2003.

MUJIKA, I. et al. The relative age effect in a professional football club setting. J Sports Sci, v. 27, n. 11, p. 1153-8, Sep 2009. Disponível em: < http://www.ncbi.nlm.nih.gov/pubmed/19714545 >.

MUSCH, J.; GRONDIN, S. Unequal Competition as an Impediment to Personal Development: A Review of the Relative Age Effect in Sport. Developmental Review, v. 21, n. 2, p. 147-167, 2001.

PEDRETTI, A.; SEABRA, A. Relative age effect and its relationship with morphological characteristics and performance in young soccer players. Brazilian Journal of Kinanthropometry and Human Performance, v. 17, n. 3, p. 367-377, 2015. 
REILLY, T.; BANGSBO, J.; FRANKS, A. Anthropometric and physiological predispositions for elite soccer. Journal of sports sciences, v. 18, n. 9, p. 669-683, 2000.

ROMANN, M.; FUCHSLOCHER, J. Relative age effects in Swiss junior soccer and their relationship with playing position. Eur J Sport Sci, v. 13, n. 4, p. 356-63, 2013. Disponível em: < http://www.ncbi.nlm.nih.gov/pubmed/23834540 >.

SEABRA, A.; MAIA, J.; GARGANTA, R. Crescimento, maturação, aptidão física, força explosiva e habilidades motoras específicas. Estudo em jovens futebolistas e não futebolistas do sexo masculino dos 12 aos 16 anos de idade. Revista Portuguesa de Ciências do Desporto, v. 1, n. 2, p. 22-35, 2001.

SEMENICK, D. TESTS AND MEASUREMENTS: The T-test. Strength Cond J, v. 12, n. 1, p. 36-37, 1990.

VAEYENS, R. et al. A multidisciplinary selection model for youth soccer: the Ghent Youth Soccer Project. Br J Sports Med, v. 40, n. 11, p. 928-34; discussion 934, Nov 2006. Disponível em: < http://www.ncbi.nlm.nih.gov/pubmed/16980535 >.

VERHULST, J. Seasonal birth distribution of West European soccer players: a possible explanation. Medical Hypotheses, v. 38, n. 4, p. 346-348, 1992.

VOTTELER, A.; HÖNER, O. The relative age effect in the German Football TID Programme: Biases in motor performance diagnostics and effects on single motor abilities and skills in groups of selected players. European journal of sport science, v. 14, n. 5, p. 433$442,2014$.

Recebido em: 07/12/2015

Revisado em: 20/05/2016

Aprovado em: 20/05/2016

Endereço para correspondência:

pedrettiaugusto@gmail.com

Augusto Pedretti

Universidade Federal de Juiz de Fora

Rua José Lourenço Kelmer, S/n

Martelos

36036-330 - Juiz de Fora, MG - Brasil 